\title{
Therapy of inflammatory bowel disease using new 5-ASA compounds: An introduction
}

\author{
ULRICH KLOTZ, PHD
}

\begin{abstract}
Strong evidence has been accumulating that mesalazine (5aminosalicylic acid, 5-ASA) represents the therapeutic moiety of the standard drug sulphasalazine. Since the active metabolite avoids the toxic potential of sulphapyridine, this perception has initiated new therapeutic approaches, for example, two 5-ASA molecules have been coupled to form another prodrug (olsalazine) which again depends on a proper cleavage of the azobond by bacteria in the colon. A more direct way has been applied successfully by administering 5-ASA itself in special galenic formulation (suppositories, enemas, controlled release preparatigns) to provide enough active material at the proposed sites of action in the terminal ileum and/or colon. One major advantage of all 5-ASA compounds, compared to sulphasalazine, is their 10-fold lower potential (incidence) for inducing allergic reactions or causing intolerance. Aside from rare hypersensitivity reactions, 5-ASA can cause nausea, vomiting, headache and gastrointestinal disturbances in 1 to $5 \%$ of patients. However, the new azocompound olsalazine induced diarrhea or loose stool in at least 10 to $15 \%$ of the treated patients which might limit its use in inflammatory bowel disease (IBD). In conclusion, the 'old' metabolite 5-ASA, in a 'new' design, offers an effective and very safe choice for the treatment of IBD. Can J Gastroenterol 1989;3(2):82-84
\end{abstract}

Key Words: Inflammatory bowel disease, Mesalazine, Olsalazine, Pharmacokinetics, Side effects, Sulphasalazine

\section{Les composés de 5-ASA et la thérapie de la maladie} \section{inflammatoire de l'intestin: Une introduction}

RESUME: Il semble de plus en plus probable que la mesalazine (acide amino-5 salicylique; 5-ASA) représente le pendant thérapeutique du médicament standard, la sulphasalazine. Le fait que ce métabolite actif permette d'éviter la toxicité potentielle de la sulphapyridine a donné lieu à de nouvelles approches thérapeutiques, par exemple, deux molécules de 5-ASA ont été accouplées pour former une autre prodrogue, l'olsalazine, qui dépend de nouveau de la division correcte du lien exoique par les bactéries du côlon. Une façon plus directe de procéder a été appliquée avec succès; le 5-ASA est lui-même administré dans une préparation

Dr Margarete Fischer Bosch Institute of Clinical Pharmacology, Stuttgart, West Germany

Correspondence and reprints: Dr Ulrich Klotz, Dr Margarete Fischer Bosch Institut fur

Klinische Pharmakologie, Auberbachstrasse 112, D-7000 Stuttgart 50, West Germany.

Telephone (0711) $8101-702$

This paper was presented at the Interfalk symposium Trends in inflammatory bowel disease therapy, Lake Louise, Alberta, April 20-23, 1988
I N THE PAST FEW YEARS STRONG EVIdence has been accumulating that 5 aminosalicylic acid or mesalazine (5ASA) represents the therapeutic moiety of the standard drug sulphasalazine (1-3). Since the active metabolite, 5-ASA, avoids the toxic potential of sulphapyridine, this new perception has initiated numerous studies whereby two different approaches have emerged.

Imitating the azocompound sulphasalazine, different and hopefully less toxic carrier molecules than sulphapyridine were attached via an azobond to 5-ASA resulting in agents such as ipsalazide and balsalazide. A more elegant development appears to be polymeric 5-ASA or olsalazine where the active compound is coupled to an inert matrix or to itself, again by azobonds. However, to become active, all of these prodrugs depend on a proper cleavage of the azobond by bacteria in the colon (3.4). For this reason, clinical efficacy can only be expected in colonic disease.

A more direct way has been applied successfully by administering 5-ASA itself. Since this salicylate is absorbed to a large extent in the stomach if administered in its plain form, a special galenic formulation had to be developed to provide enough active material at the proposed sites of action $(3,4)$. In the case of ulcerative colitis and proctitis this goal has been achieved by enemas and suppositories, In Crohn's disease, where parts of the small bowel are often in- 
galénique spéciale (suppositoires, lavements, préparations à largage contrôlé) pour fournir assez de substances actives aux sites visés dans l'iléum terminal et/ou le côlon. Un des grands avantages de tous les composés à base de 5-ASA - comparés à la sulphasalazine - c'est leur potentiel 10 fois moindre de produire des réactions allergiques ou l'intolérance. Mis à part de rares réactions hypersensibles, le 5-ASA peut provoquer des vomissements, des céphalées et des troubles gastrointestinaux (1 à $5 \%$ des patients). Néanmoins, le nouveau composé azoïque olsalazine a provoqué des diarrhées ou des selles molles chez au moins 10 à $15 \%$ des patients traités, ce qui pourrait limiter son utilisation. En conclusion, l'ancien métabolite 5-ASA offre sous son nouveau design, un choix efficace et très sûr, de traitement des maladies inflammatoires de lintestin. volved, the problem has been improved by developing special oral preparations with controlled slow release mechanisms (1-3).

\section{CHARACTERISTICS OF 5-ASA COMPOUNDS}

Table 1 summarizes some pharmacokinetic data of those 5-ASA compounds which are now available in different countries for the oral treatment of inflammatory bowel disease (IBD). Whereas Salofalk (Interfalk, Mont-Saint-Hilaire, Quebec), Pentasa (Ferring A/S, Vanlose, Denmark) and Asacol (Norwich-Eaton, Cambridge, Ontario) deliver 5-ASA directly to the small and large bowel (5-9), olsalazine delivers 5-ASA only to the colon (10). The different release pattern is accomplished by variation in the coating and buffering system which is also $\mathrm{pH}$ dependent. Plasma concentrations of 5-ASA and its major acetylated metabolite are low because only part of the active drug is absorbed which can also be visualized from the low urinary recovery, ranging from 20 to $50 \%$. Considerable amounts of total 5-ASA can be recovered from feces, indicating that sufficient material is available for the supposed local action (7-11). Recently, a crossover study using healthy volunteers confirmed the well described disposition pattern of the different 5-ASA compounds (12).

\section{TOXICOLOGICAL ASPECTS}

During the past 10 years a sufficiently higher number of patients has been treated, mainly on a long term basis, with the new 5-ASA compounds to establish the toxic potential of this well known metabolite. Compared to sulphasalazine, all 5-ASA compounds offer one major advantage: numerous crossover studies have clearly demonstrated that 5-ASA has about a 10 -fold lower potential for inducing allergic reactions or causing intolerance (Table 2). In some rare cases, as known from other salicylates, 5-ASA

\section{TABLE 1}

Biopharmaceutical and pharmacokinetic properties of oral 5-ASA compounds

\begin{tabular}{|c|c|c|c|c|}
\hline & $\begin{array}{l}\text { Salofalk (7) } \\
\text { (patients) }\end{array}$ & $\begin{array}{l}\text { Pentasa (8) } \\
\text { (volunteers) }\end{array}$ & $\begin{array}{l}\text { Asacol (9) } \\
\text { (patients) }\end{array}$ & $\begin{array}{l}\text { Olsalazine (10) } \\
\text { (volunteers) }\end{array}$ \\
\hline $\begin{array}{l}\text { Galenic } \\
\text { formulation }\end{array}$ & $\begin{array}{l}\text { Cellulose ether, } \\
\text { Eudragit } \mathrm{L} \text {. } \\
\mathrm{Na}_{2} \mathrm{CO}_{2} \text { buffering }\end{array}$ & $\begin{array}{l}\text { Coating with } \\
\text { efhyl cellulose }\end{array}$ & $\begin{array}{l}\text { Coating with } \\
\text { Eudragits }\end{array}$ & Azocompound \\
\hline $\begin{array}{l}\text { Release } \\
\text { mechanism }\end{array}$ & $\mathrm{pH}$ dependent & pH dependent & $\mathrm{pH}$ sensitive & $\begin{array}{l}\text { Bacterial } \\
\text { cleavage }\end{array}$ \\
\hline$C_{\max }(\mu \mathrm{g} / \mathrm{mL})$ & 0.3 to 1.5 & $\begin{array}{l}1.1 \text { to } 2.9 \\
\text { (AC-5-ASA) }\end{array}$ & 0.1 to 9.7 & 0.1 to 0.8 \\
\hline Urinary recovery & $\begin{array}{l}44 \% \\
(11 \% 5-A S A \\
33 \% \text { AC- } 5 \text {-ASA })\end{array}$ & $\begin{array}{l}53 \% \\
(12 \% 5-A S A \\
41 \% \text { AC- } 5-A S A)\end{array}$ & $20 \%$ & $16 \%$ \\
\hline Fecal recovery & $\begin{array}{l}35 \% \\
(16 \% 5-A S A \\
19 \% \text { AC- } 5-A S A)\end{array}$ & $\begin{array}{l}40 \% \\
(14 \% 5-A S A \\
26 \% \text { AC-5-ASA })\end{array}$ & - & $\begin{array}{l}28 \% \\
(21 \% 5-A S A \\
7 \% \text { AC-5-ASA })\end{array}$ \\
\hline $\begin{array}{l}\text { Fecal recovery (12) } \\
\text { (volunteers) }\end{array}$ & $\begin{array}{l}5 \% 5-A S A \\
32 \% \text { AC- } 5 \text {-ASA }\end{array}$ & $\begin{array}{l}9 \% 5-\mathrm{ASA} \\
38 \% \text { AC- } 5 \text {-ASA }\end{array}$ & $\begin{array}{l}7 \% 5-A S A \\
33 \% \text { AC- } 5 \text {-ASA }\end{array}$ & $\begin{array}{l}13 \% 5 \text {-ASA } \\
39 \% \text { AC- } 5 \text {-ASA }\end{array}$ \\
\hline
\end{tabular}

TABLE 2

Incidence of intolerance or allergic reactions to sulphasalazine and 5-ASA in several crossover studies

\begin{tabular}{ccc}
\hline $\begin{array}{c}\text { Number of patients with } \\
\text { intolerance or allergic } \\
\text { reactions to }\end{array}$ & \\
$\begin{array}{c}\text { Sulfasalazine } \\
(n=411)\end{array}$ & $\begin{array}{c}5 \text {-ASA } \\
(n=40)\end{array}$ & References \\
\hline 35 & 3 & 17 \\
24 & 4 & 18 \\
15 & 2 & 19 \\
7 & 0 & 20 \\
5 & 0 & 21 \\
37 & 4 & 22 \\
109 & 6 & 23 \\
5 & 0 & 24 \\
66 & 2 & 25 \\
50 & 7 & 26 \\
58 & 12 & 27 \\
\hline
\end{tabular}

can cause allergic or pseudoallergic reactions. However, in contrast to acetylsalicylic acid, 5-ASA does not affect platelet aggregation (13, unpublished data). Similarly, in contrast to sulphasalazine, there are no fertility problems with 5-ASA in males and all the numerous sulphapyridine-induced side effects of sulphasalazine can be avoided by switching to mesalazine (1-3).

Some subjective symptoms such as nausea, vomiting, gastrointestinal disturbance or headache have been observed in 1 to $5 \%$ of patients. These most likely are caused by 5 -ASA but might sometimes be due to the underlying disease. However, in terms of gastrointestinal side effects there is a clear difference between 5-ASA and olsalazine. Only the new prodrug induces diarrhea or loose stools in at least 10 to $15 \%$ of the treated patients (14) which might limit its use in IBD Based on rat experiments with excessive

TABLE 3

Hypotheses on the mode of action of 5-ASA

5-ASA inhibits nitrite stimulated butyrate oxidation in epithelial cells from colon

5-ASA interferes with neutrophil functions

5-ASA (Ac-5-ASA) inhibits leukotrienesynthesis

5-ASA is a potent scavenger of free oxygen radicals 
intravenous dosing, a nephrotoxic potential of 5-ASA has been discussed. Careful monitoring of kidney function has failed to detect renal side effects in man $(15,16)$.

\section{CONCLUSION}

As has been outlined, there are many similarities and some differences in the

ACKNOWLEDGEMENTS: This work was supported by the Robert Bosch Foundation. Stuttgart, West Germany.

\section{REFERENCES}

1. Williams CN. Clinical experience with 5-aminosalicylate preparations in inflammatory bowel disease - A review. Can J Gastroenterol 1987:1:28-32

2. Meyers $\mathrm{S}$. The place of oral 5 -aminosalicylic acid in the therapy of ulcerative colitis. Am J Gastroenterol 1988:83:64-7.

3. Klotz U, Maier KE. Pharmacology and pharmacokinetics of 5-aminosalicylic acid, Dig Dis Sci 1987:32:46s-50s

4. Klotz U. Clinical pharmacokinetics of sulphasalazine, its metabolites and other prodrugs of 5-aminosalicylic acid. Clin Pharmacokinet 1985;10:285-302.

5. Hardy JG, Healey JN. Lee SW, Reynolds JR. Gastrointestinal transit of an enteric-coated delayed-release 5-aminosalicylic acid tablet. Aliment Pharmacol Ther 1987:1:209-16.

6. Hardy JC, Healey JNC. Reynolds JR. Evaluation of an enteric-coated delayed-release 5-aminosalicylic acid tablet in patients with inflammatory bowel disease. Aliment Pharmacol Ther 1987:1:273-80

7. Klotz U, Maier KE, Fischer C, Bauer $\mathrm{KH}$. A new slow-release form of 5-aminosalicylic acid for the oral treatment of inflammatory bowel disease: Biopharmaceutic and clinical pharmacokinetic characteristics. Arzneimittelforsch (Drug Res) 1985;35:636-9.

8. Rasmussen SN, Bondesen S, Hvidberg E. et al. 5-aminosalicylic acid in a slow-release preparation: Bioavailability, plasma level, and excretion in humans. Gastroenterology 1982;83:1062-70.

9. Dew MJ, Ryder REJ, Evans N. Evans BK, Rhodes J. Colonic release of 5-aminosalicylic acid from an oral preparation in active ulcerative colitis. $\mathrm{Br}$ J Clin Pharmacol 1983;16:185-7. clinical pharmacology of the new 5-ASA compounds which should be considered if selecting a particular 5-ASA compound. The clinical introduction of these effective drugs, which have a remarkably low incidence of side effects, has also opened and initiated new lines of basic research. According to several in vitro and in vivo studies different mechanisms

10. Willoughby CP, Aronson JK, Agback H, Bodin NO, Truelove SC. Distribution and metabolism in healthy volunteers of disodium azodisalicylate, a potential therapeutic agent in ulcerative colitis. Gut 1982;23:1081-7.

11. Bondesen S, Nielsen OH, Schou JB, et al. Steady-state kinetics of 5-aminosalicylic acid and sulphapyridine during sulphasalazine prophylaxis in ulcerative colitis. Scand J Gastroenterol 1986;21:693-700

12. Rijk MCM, van Schaik A, van Tongeren JHN. Disposition of 5-aminosalicylic acid by 5 -aminosalicylic acid-delivery compounds. Scand J Gastroenterol 1988;23:107-12

13. Winther K, Bondesen S, Hansen SH, Hvidberg E. Lack of effect of 5-aminosalicylic acid on platelet aggregation and fibrinolytic activity in vivo and in vitro. Eur J Clin Pharmacol 1987:33:419-22.

14. Sandberg-Gertzen H, Jarnerot $G$, Kraaz W. Azodisal sodium in the treatment of ulcerative colitis. A study of tolerance and relapse-prevention properties. Gastroenterology 1986; 90:1024-30.

15. Diener U, Tuczek HV, Fischer C, Maier K, Klotz U. Renal function was not impaired by treatment with 5-aminosalicylic acid in rats and man. Naunyn Schmiedebergs Arch Pharmacol 1984;326:278-82

16. Campieri M, Brignola C, Bazzocchi G, et al. Several aspects of topical treatment with 5-aminosalicylic acid enemas. In: Ewe K, Fahrländer Hm, eds. Therapie chronisch entzundlicher Darmerkrankungen - Fortschritte, Entwicklungen, Tendenzen. Stuttgart, New York: Schattauer, 1986:237-42.

17. Dew MJ, Harries AD, Evans N, Evans BK, Rhodes J. Maintenance of remission in ulcerative colitis with 5-aminosalicylic acid in high dose by mouth. Br Med J 1983;287:23-4

18. Campieri M, Lanfranchi GA, Brignola C. Bazzocchi G, Minguzzi MR, Calari for the action of 5-ASA are being discussed, which need not necessarily be mutually exclusive (Table 3). Most appealing is the fact that 5-ASA represents a potent free oxygen radical scavenger and may also inhibit leukotriene synthesis. In conclusion, the 'old' metabolite, 5-ASA, offers an effective new and less toxic choice for the treatment of IBD

MT. 5-Aminosalicylic acid as rectal enema in ulcerative colitis patients unable to take sulphasalazine. Lancet 1984;i:403

19. Austin CA, Cann CA, Jones TH Holdsworth CD. Exacerbation of diarrhea and pain in patients treated with 5-aminosalicylic acid for ulcerative colitis. Lancet 1984;i:917-8.

20. Hanauer SB, Schultz PA, Kirsner JB. Treatment of refractory proctitis with 5-ASA enemas. Gastroenterology 1985;88:1412.

21. Schröder KW, Tremaine WJ Corticosteroid dependent chronic ulcerative colitis: Favourable response to oral 5-aminosalicylic acid Gastroenterology 1985;88:1388

22. Donald IP, Wilkinson SP. The value of 5-aminosalicylic acid in inflammatory bowel disease for patients intolerant or allergic to sulphasalazine. Postgrad Med ] $1985 ; 61: 1047-8$

23. Sandberg-Gertzen H, Järnerot G, Kraaz W. Azodisal sodium in the treatment of ulcerative colitis. Gastroenterology 1986:90: 1024-30.

24. Hetzel DJ, Shearman DJC, Bochner E, et al. Azodisalicylate (olsalazine) in the treatment of active ulcerative colitis. A placebo controlled clinical trial and assessment of drug disposition. Gastroenterol Hepatol 1986;1:257-66.

25. Meyers S, Sachar DB, Present DH. Janowitz HD. Olsalazine sodium in the treatment of ulcerative colitis among patients intolerant to sulfasalazine. Gastroenterology 1987:93:1255-62.

26. Turnunen U, Elomaa I. Anttila V-J. Seppälä K. Mesalazine tolerance in patients with inflammatory bowel disease and previous intolerance or allergy to sulphasalazine or sulphonamides. Scand J Gastroenterol 1987;22:798-802

27. Rao SS, Cann PA, Holdsworth CD. Clinical experience of the tolerance of mesalazine and olsalazine in patients intolerant of sulphasalazine. Scand J Gastroenterol 1987;22:232-6. 


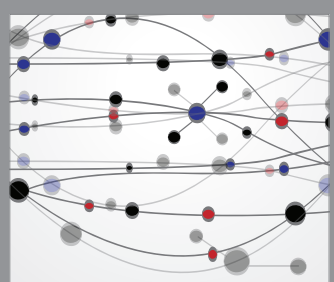

The Scientific World Journal
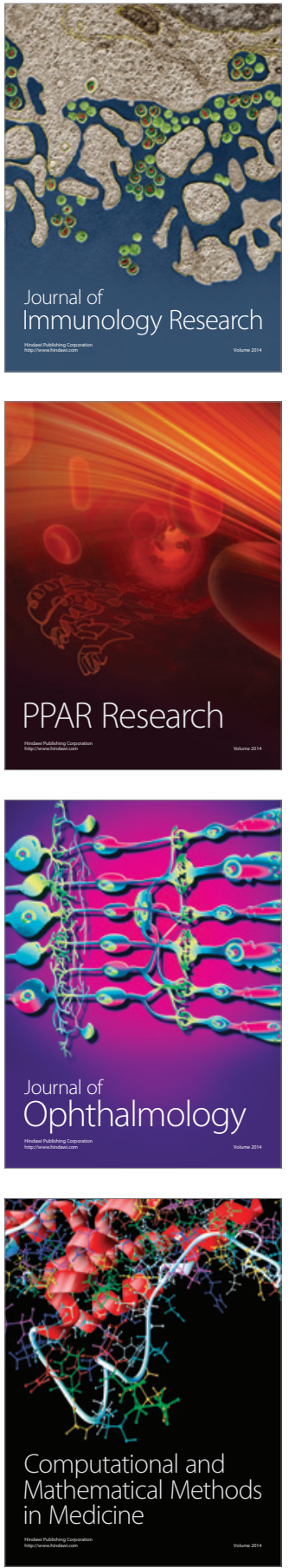

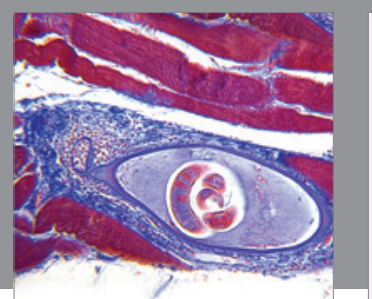

Gastroenterology Research and Practice

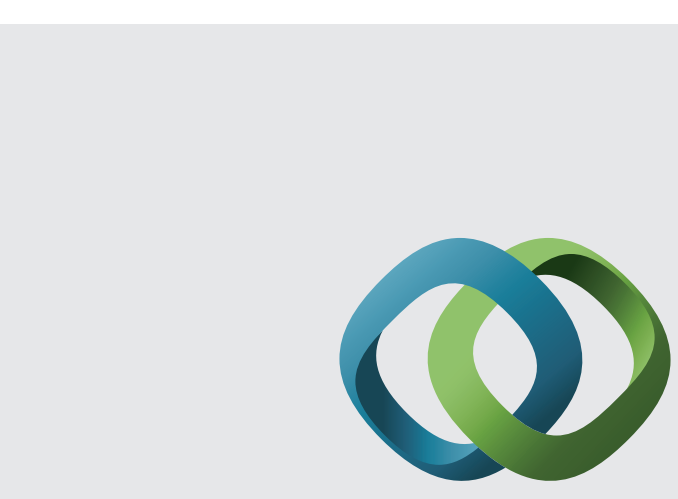

\section{Hindawi}

Submit your manuscripts at

http://www.hindawi.com
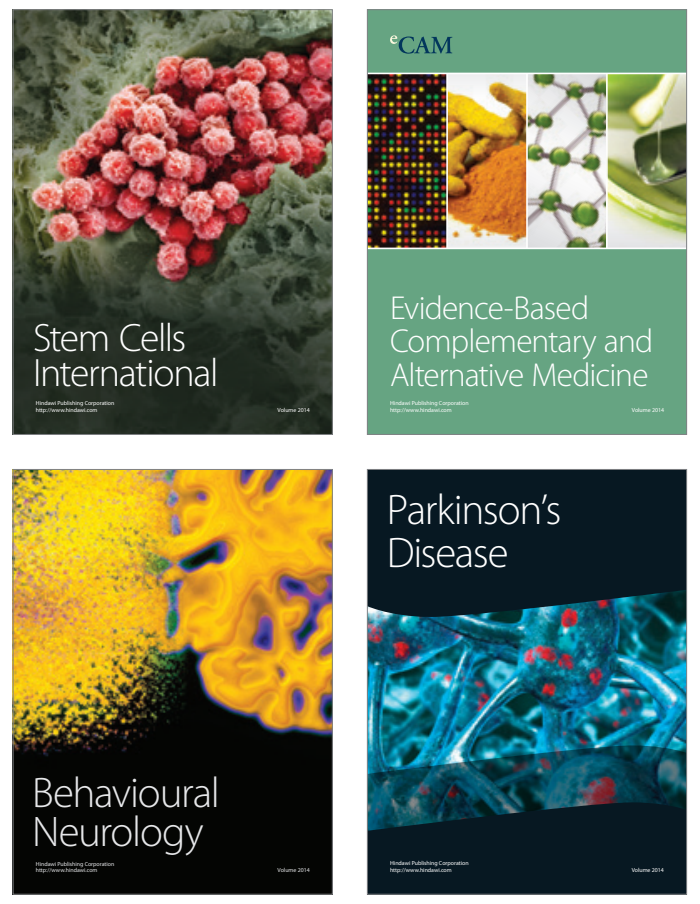
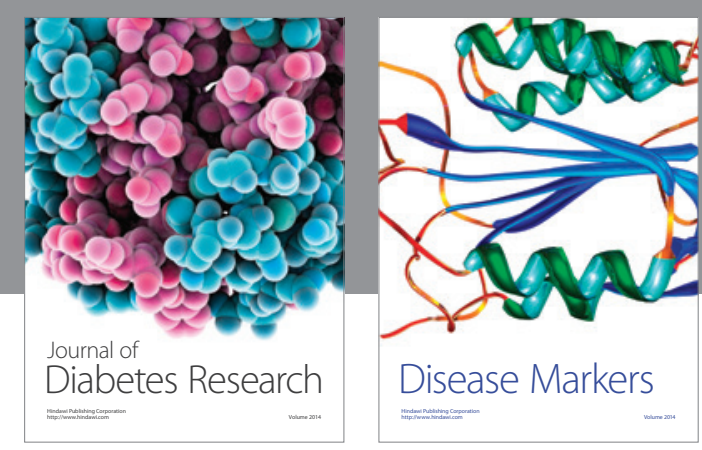

Disease Markers
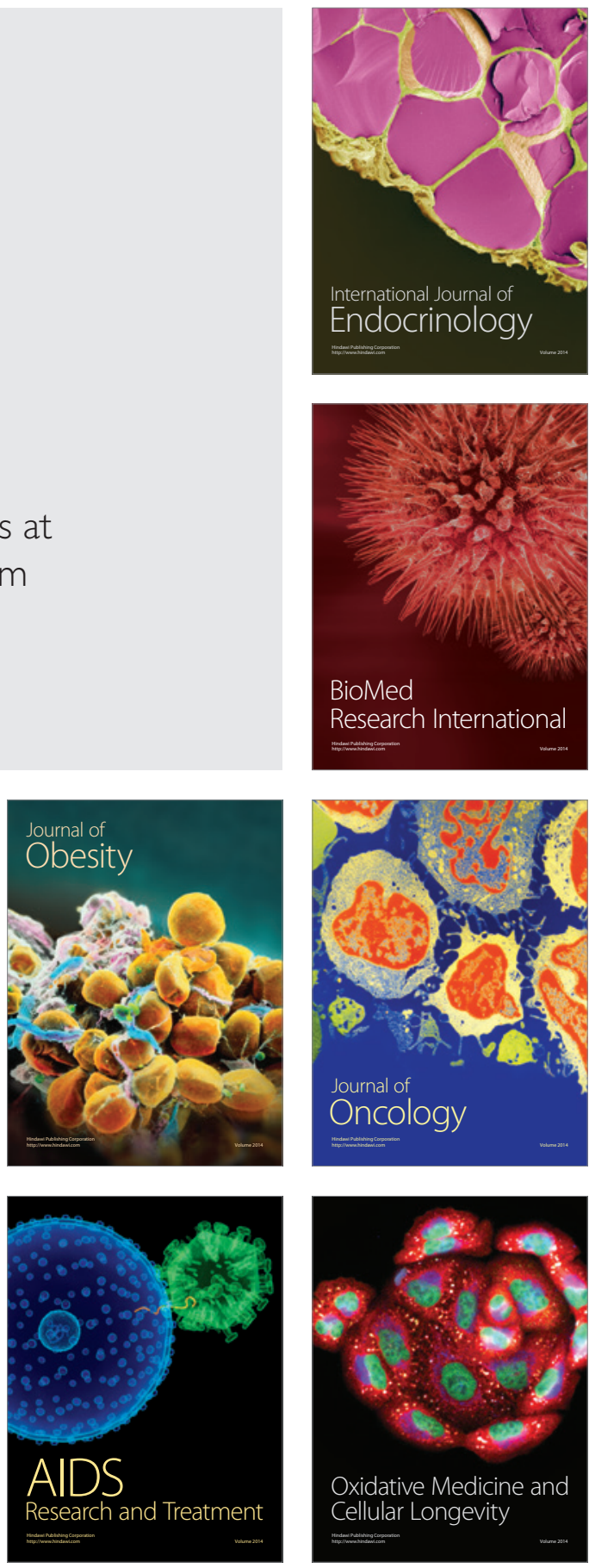